\title{
LARVAL MORPHOLOGY OF THE WATER MITE HYDRYPHANTES SAMARICUS TUZOVSKIJ (ACARI, HYDRACHNIDIA: HYDRYPHANTIDAE)
}

\section{Petr V. Tuzovsky}

Institute for Biology of Inland Waters, Russian Academy of Sciences, Borok, Yaroslavl Prov., Russia

E-mail: tuz@ibiw.yaroslavl.ru

ABSTRACT: The first illustrated description of the water mite larva Hydryphantes samaricus is given.

KEY WORDS: Hydryphantidae, Hydryphantes samaricus, water mite, larva, morphology.

DOI: $10.21684 / 0132-8077.2016 .24 .1 .51 .54$

\section{INTRODUCTION}

The water mite Hydryphantes samaricus Tuzovskij, 2014 was described from the male, female, and deutonymph from the Samara Province (Tuzovskij 2014a). Larva of this species was previously unknown. The aim of the paper is to describe larva of this water mite.

\section{MATERIAL AND METHODS}

The material was collected by the author in the Yaroslavl Province of Russia. To obtain larvae, water mites were maintained in the laboratory (room temperature, natural day-night conditions).

Idiosomal setae are named according to $\mathrm{Tu}$ zovskij (1987): $F c h$-frontales chelicerarum, $F p$ frontales pedipalporum, $V i$-verticales internae, $\mathrm{Ve}$-verticales externae, $\mathrm{O} i$ - occipitales internae, $\mathrm{Oe}$-occipitales externae, $\mathrm{Hi}$ - humerales internae, $\mathrm{He}$-humerales externae, $\mathrm{Hv}$-humerales ventralia, Sci-scapulares internae, $\mathrm{Sce}$-scapulares externae, $L i$-lumbales internae, $L e$-lumbales externae, $\mathrm{Si}$ - sacrales internae, $\mathrm{Se}$ - sacrales externae, $C i$ - caudales internae, $P i-$ praeanales internae, $P e$ - praeanales externae, $A i$ - anales internae, $A e$ - anales externae.

Furthermore, the following abbreviations are used: P-1-5, pedipalp segments (trochanter, femur, genu, tibia, and tarsus); I-Leg-1-6, first leg, segments 1-6 (trochanter, basifemur, telofemur, genu, tibia and tarsus) i.e. III-Leg-1 - trochanter of third leg; $\mathrm{C} 1$ - coxal setae located posteromedially on coxa I, C2 - coxal seta located posterolaterally on coxa I, C4 - coxal seta located anteriorly on coxa III, $s$ - solenidion, $e$ - eupathidium, $a c$ - acanthoid seta; I-Leg-6: de-distance between the anterior end of segment and eupathidium, $d s$-distance between the anterior end of segment and solenidion; L-length; $\mathrm{W}$ - width; $\mathrm{n}$ = number of specimens measured; all measurements are given in micrometers $(\mu \mathrm{m})$.

\section{Family Hydryphantidae Piersig, 1896}

Genus Hydryphantes Koch, 1841

Hydryphantes samaricus Tuzovskij, 2014

(Figs 1-11)

Material examined. 42 larvae were reared from four females (Yaroslavl Province). The duration of the embryonic period was 10-14 days.

Diagnosis. Distance between bases of trichobothria $O i$ larger than their length, setae $F c h$ and $V i$ subequal; all dorsal hysterosomal setae subequal; median eye situated between rows of setae $V i$ and $O i$; urstigma rather wider than long; chelicera with numerous thin strips; P-5 with moderately long solenidion; I/II-Leg-4 solenidion longer than eupathidium; I/II-Leg-5 with subequal solenidia; I-Leg-6 de $<d s$.

Description. Color red. Anterior pair of platelets small, more or less triangular; posterior plate relatively large, anteriorly narrow, posteriorly widening; median eye rather large and situated between rows of setae $V i$ and $O i$ (Fig. 1). Both pairs of trichobothria thin, $F p$ very long, $O i$ short. Distance between bases of trichobothria $\mathrm{Oi}-\mathrm{Oi}$ larger than their length. Simple proterosomal setae $(F c h$ and $V i)$ thick and subequal. Other dorsal setae (Oe, Hi, He, Sci, Sce, $\mathrm{Li}$ and $\mathrm{Le}$ ) thick and subequal.

Coxal plates II triangular, coxal plates I and III more or less trapezoidal and rounded medially (Fig. 2); all coxal setae relatively short and subequal. Urstigma oval, rather wider than long. Setae $\mathrm{Si}$ longer and thicker than other ventral idiosomal setae. Setae $\mathrm{Se}, \mathrm{Ci}, \mathrm{Pi}$ and $\mathrm{Pe}$ subequal and slightly longer and thicker than both pairs of anal setae $(A i, A e)$.

Excretory pore plate small, usually wider than long or nearly as long as wide (L/W ratio $0.67-$ 0.95 ), excretory pore and bases of setae $A i$ located near posterior plate margin (Figs 3-4). 
P. V. Tuzovsky

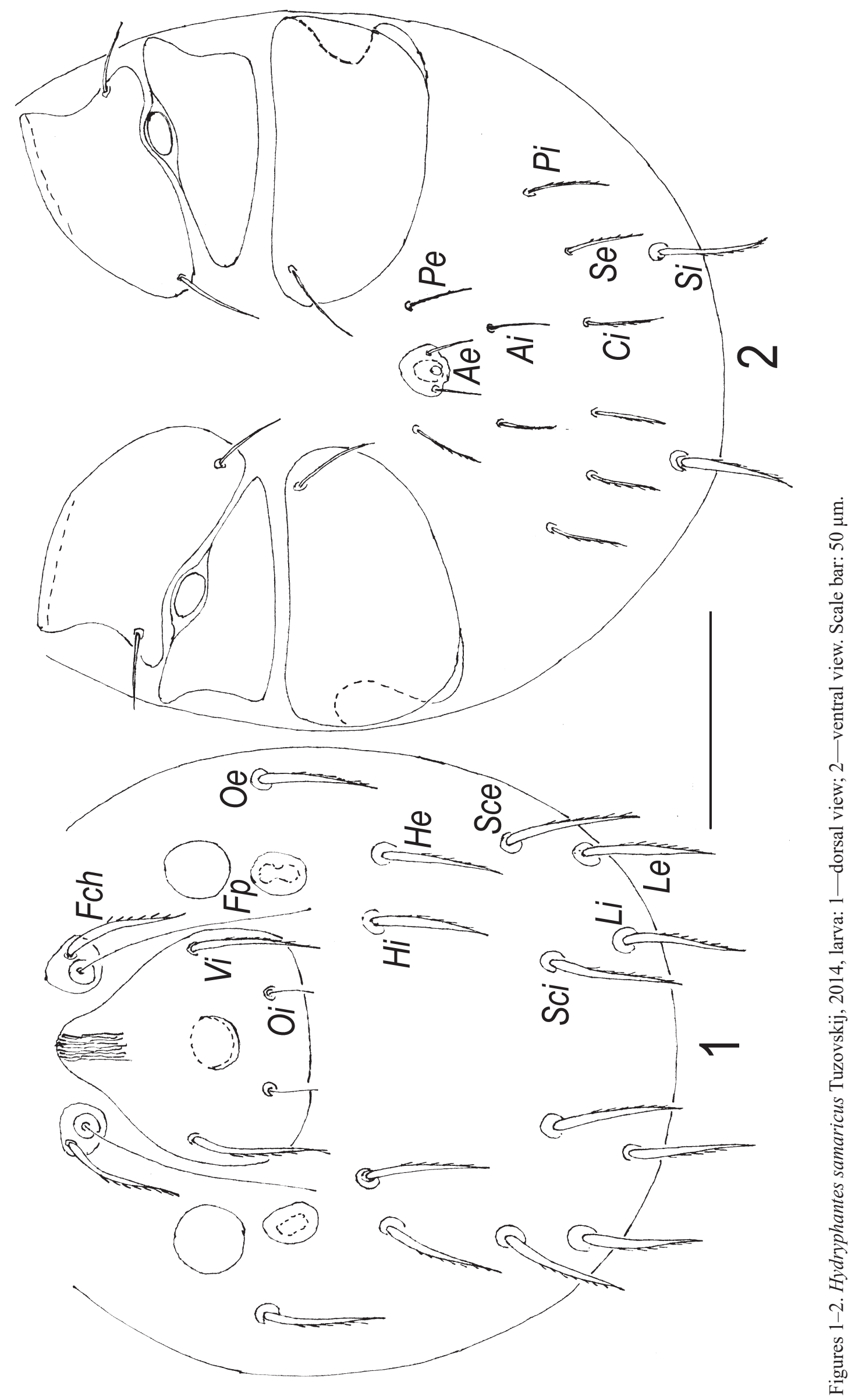




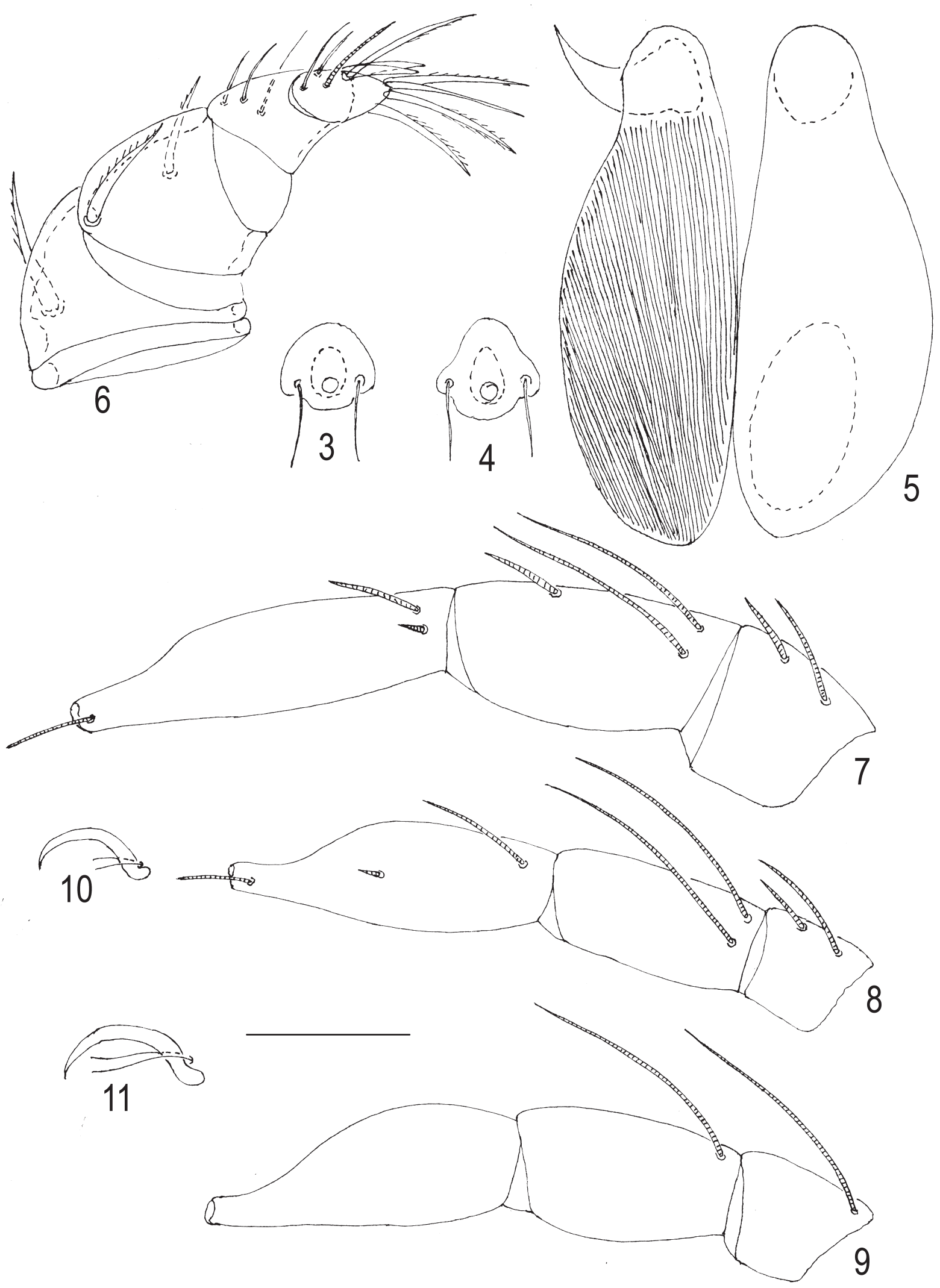

Figures 3-11. Hydryphantes samaricus Tuzovskij, 2014, larva: 3-4 - excretory pore plate; 5-chelicerae; dorsal view, 6- pedipalp; 7-I-Leg-4-6; 8-II-Leg-4-6; 9-III-Leg-4-6; 10 — claws of leg I; 11 — claws of leg III. Simple setae on I-III-Leg-4-6 not shown. Scale bar $=25 \mu \mathrm{m}$. 
Chelicera (Fig. 5) with large basal segment and small chela. Basal segment with numerous thin strips, chela short, without apical teeth.

Pedipalps stout (Fig. 6): P-1 very short and without setae, $\mathrm{P}-2$ large with convex dorsal margin and single proximal dorsal setae; P-3 with two subequal setae (proximal and distal); P-4 with three thin unequal setae, dorsodistal claw large with two subequal clawlets; P-5 small, with a single moderately long solenidion and seven setae: five long and thick, two short and thin.

Shape and arrangement of specialized setae on terminal segments as shown in Figs 7-9. I/II-Leg-4 solenidion 1.5-2.0 times longer than eupathidium, I/II-Leg-5 proximal solenidia subequal, I-Leg-6 eupathidium short and situated anteriorly to the solenidion basis; II-Leg-6 solenidion in proximal, eupathidium in submedial position; III-Leg-4-5 with subequal proximal solenidion. Empodium large and crescent-shaped on all tarsi, ambulacra short and thin (Figs 10-11).

Measurements, $\mathrm{n}=10$. Dorsal plate L 35-40, W 38-42; setae Fch L 19-23, setae Fp L 40-45, setae $V i$ L 21-26, setae $O i$ L 6-9, setae $O e, H i, H e$, $\mathrm{Sci}$, Sce, Li, Le and Si L 19-23; setae Ci, Se, Pi, Pe 11-13; setae $A i$ and $A e$ 8-10; distance between setae $\mathrm{Vi}-\mathrm{Vi}$ 34-36, distance between setae $\mathrm{Oi}-\mathrm{Oi}$ 16-20; excretory pore plate L 6-8, W 9-11; urstigma L 6-7, W 9-10; basal segments of chelic- erae L 57-61, chela L 11-13; pedipalpal segments (P-1-5) L: 6-7, 28-30, 15-17, 19-20, 11-13; leg segments L: I-Leg-1-6: 22-24, 12-13, 15-16, 22-24, 28-32, 47-49; II-Leg-1-6: 19-23, 10-13, 9-13, 14-16, 24-26, 36-39; III-Leg-1-6: 20-24, 11-15, 11-13, 14-16, 27-29, 35-39.

Remarks. The larva of the present species is similar to the larva of $H$. planus Thon, 1899 . However, the following clear differences can be found in their morphology (character states of H. planus are given in parentheses after Tuzovskij 2014b): the setae $F c h$ shorter than $F p$ (subequal); I-Leg-4 solenidion longer than eupathidium (subequal); I-Leg- $6 d s>d e(\mathrm{I}-\mathrm{Leg}-6 d s=d e)$.

\section{REFERENCES}

Tuzovskij, P.V. 1987. Morfologiya i postembrional'noye razvitiye vodyanykh kleshchey [Morphology and Postembryonic Development in Water Mites]. Nauka Publ., Moscow, 172 pp. [in Russian]

Tuzovskij, P.V. 2014a. Description of a new water mite species of the genus Hydryphantes Koch (Acari, Hydrachnidia, Hydryphantidae) from Russia. Acarina, 22 (2): 122-126

Tuzovskij, P.V. 2014. Larval morphology of Hydryphantes clypeatus Thor, 1899, H. dispar Schaub, 1888 and H. planus Thon, 1899 (Acari, Hydrachnidia: Hydryphantidae). Zootaxa, 3869 (2): 131142. 